\title{
GOMMENTS
}

\section{A NON-CONFLICT APPROACH TO THE FIRST AMENDMENT RELIGION GLAUSES}

\section{INTRODUCTION}

In 1963, the United States government completed construction of Glen Canyon Dam on the Colorado River. The water slowly began to back up behind the dam creating the immense expanse of Lake Powell from what had once been desert. ${ }^{1}$ That desert area had a special significance to the Navajo Indians-it was the site of important shrines and the home of various Navajo deities. ${ }^{2}$ Native traditions taught that if humans tampered with the area, the Indian prayers would not be heard by the gods and would no longer be efficacious in preventing evil and disease. In addition, the presence of tourists, who now came by boat to visit the once isolated Rainbow Bridge, prevented the Indians from practicing ceremonials essential to their religion. ${ }^{3}$ To protect their place of worship, the Navajos brought suit in Badoni v. Higginson, arguing that the government actions infringed upon the practice of their native religion and thereby violated the free exercise clause of the first amendment. ${ }^{5}$ What the tribe demanded, in the name of religious freedom, was preferential use of the government land and resources. ${ }^{6}$

The Badoni court dealt with the Navajo claim by posing a conflict between the establishment and free exercise clauses of the first amend-

1 Badoni v. Higginson, 638 F.2d 172, 174-76 (10th Cir. 1980), cert. denied, 452 U.S. 954 (1981).

2 Id.

$3 I d$.

638 F.2d 172 (10th Cir. 1980), cert. denied, 452 U.S. 954 (1981).

- The first amendment proscriptions begin with religion: "Congress shall make no law respecting an establishment of religion or prohibiting the free exercise thereof ...."U.S. ConsT. amend. I.

- Both Badoni and Hopi Indian Tribe v. Block, No. 81-0481 (D.D.C. June 12, 1981) (available Dec. 1, 1982, on LEXIS, Genfed Library, Dist. file), involved other claims and issues not dealt with in this Comment. For example, in Badoni, plaintiffs claimed that in impounding water in Lake Powell, the government had drowned some of the plaintiffs' gods and therefore violated their free exercise rights. Plaintiffs also contended that the failure to provide an environmental impact statement was a violation of 42 U.S.C. $\$ \S 4331-4335$ (1976). Badoni, 638 F.2d at 176. In Hopi Indian Tribe, in addition to the free exercise claim, plaintiffs brought suit under the American Indian Religious Freedom Act, 42 U.S.C. § 1996 (Supp. IV 1980), the National Environmental Policy Act, 42 U.S.G. $\$ \S 4321-4361$ (1976), the Endangered Species Act, 16 U.S.C. $\S \S 1531-1543$ (1976), and other statutes. 
ment. ${ }^{7}$ The Tenth Circuit recognized, at least implicitly, the validity of the free exercise claims and the burden placed upon the native religion, ${ }^{8}$ but argued that any government action to correct such a burden

7 Badoni is representative of the kinds of problems faced by numerous Native American groups whose religious lives have been disrupted by government land and resource development policies. The report accompanying the American Indian Religious Freedom Act, 42 U.S.C. $§ 1996$ (Supp. IV 1980) [hereinafter cited as AIRFA], refers to the problem of unthinking government policies and the havoc that those policies wreaked on Native American religions. "[A] lack of U.S. governmental policy has allowed infringement in the practice of native traditional religions." H.R. REP. No. 1308 , 95th Cong., 2d Sess. 1 (1978). "[I]t appears that in nearly all cases the infringements which have occurred have not resulted from an express Federal policy, but rather from a lack of policy at the Federal level." Id. at 4.

For other cases in which Native American groups have bought suit to prevent infringements due to government land management policies, see Sequoyah v. T.V.A., 620 F.2d 1159 (6th Cir. 1980); Crow v. Gullet, 541 F. Supp. 785 (D.S.D. 1982); Hopi Indian Tribe v. Block, No. 81-0481, slip op. (D.D.C. June 12, 1981) (available Dec. 1, 1982, on LEXIS, Genfed library, Dist file).

The free exercise claim in Badoni, however, is somewhat unusual. Free exercise claims ordinarily involve a situation in which a government dictate compels an individual to violate his beliefs, see, e.g., Wisconsin v. Yoder, 406 U.S. 305 (1972) (state law requiring compulsory high school education unconstitutional as applied to Amish); West Virginia State Bd. of Educ. v. Barnette, 319 U.S. 624 (1943) (state law requiring all students to salute the flag unconstitutional), or imposes some cost on adherence to a particular religious belief, see, e.g., Thomas v. Review Bd., 450 U.S. 707 (1981) (state unemployment law denying benefits to Jehovah's Witness who terminates his job because of religious beliefs unconstitutional); Braunfeld v. Brown, 366 U.S. 599 (1966) (state Sunday closing laws upheld as applied to merchants who closed on Saturdays for religious reasons); Sherbert v. Verner, 374 U.S. 398 (1963) (state unemployment law denying benefits to Seventh Day Adventist unavailable for Saturday work unconstitutional). The Badoni situation, in contrast, did not force any individual to make a choice of conscience between his religion and the law. Members of the tribe were permitted access to the sacred areas along with the rest of the public, and no attempt was made to prevent the performance of religious ceremonies. The tribe claimed, however, that the opening of the land to the public in itself desecrated sacred areas and the presence of tourists denied the religious practitioners the privacy necessary to perform religious rituals. 638 F.2d at 177 . Similar claims have been raised in a number of other cases. See, e.g., Crow v. Gullet, 541 F. Supp. 785 (D.S.D. 1982), in which leaders of two Indian nations objected to state development of a park area containing Bear Butte, a geological structure sacred to the tribes. Plaintiffs objected to the building of roads, bridges, and access facilities and complained that the presence of tourists disturbed them in their religious exercises. See also Sequoyah v. T.V.A., 620 F.2d 1159 (6th Cir. 1980) (Cherokees brought suit to enjoin the proposed impoundment of a reservoir which would flood land alleged to be sacred to the tribal religion); Hopi Indian Tribe (tribes objected to the recreational development of the San Francisco Peaks in Arizona on the grounds that such development desecrated sacred areas).

As this Comment went to press, the Northern District of California, in a case similar to Badoni, ruled that "[a]ctions compelled by the Free Exercise Clause do not violate the Establishment Clause." Northwest Indian Cemetery Protective Ass'n v. Peterson, 565 F. Supp. 586, 597 (N.D. Cal. 1983) (enjoining the government from harvesting timber and constructing a road on Indian ceremonial land).

${ }^{8}$ Badoni, 638 F.2d at 178. Compare Crow v. Gullet, 541 F. Supp. 785, 794 (D.S.D. 1982) and Sequoyah v. T.V.A., 620 F.2d 1159, 1165 (6th Cir. 1980) in which the courts directly denied the validity of the free exercise claims. In Hopi Indian Tribe v. Block, No. 81-0481 (D.D.C. June 12, 1981) (available Dec. 1, 1982, on LEXIS, 
would violate the establishment clause. ${ }^{\theta}$

The case raises a vexing "conflict" between the religion clauses of the first amendment, a conflict which has been discussed extensively by commentators ${ }^{10}$ and mentioned by courts, ${ }^{11}$ but has never been dealt with by the Supreme Court in a manner that would afford firm and consistent guidance to lower courts.

It is difficult to determine what constitutes an establishment clause violation when the government acts in response to a free exercise claim-do the two clauses conflict and, if so, how should that conflict be resolved ${ }^{12}$ This Comment argues that the conflict is illusory. The

Genfed Library, Dist. file), the court, while explicitly denying the first amendment violation, admitted implicitly that the government action had at least some "indirect" effect on the religion.

${ }^{\circ}$ Badoni, 638 F.2d at 178-79. See also Hopi Indian Tribe v. Block, No. 81-0481, slip op. at 6 (D.D.C. June 12, 1981) (available Dec. 1, 1982, on LEXIS, Genfed Library, Dist. file), where the court used this as an alternative argument.

10 See infra notes $43,61, \& 65-75$ and accompanying text.

11 See infra notes 39-64 and accompanying text.

12 These questions have implications as well for testing the constitutionality of the American Indian Religious Freedom Act, 42 U.S.C. $\S 1996$ (Supp. IV 1980), the avowed purpose of which specifically is to protect the religious freedom of Indian tribes:

On and after August 11, 1978, it shall be the policy of the United States to protect and preserve for American Indians their inherent right of freedom to believe, express, and exercise the traditional religions of the American Indian, Eskimo, Aleut, and Hawaiians, including but not limited to access to sites, use and possession of sacred objects, and the freedom to worship through ceremonials and traditional rites.

Id. Section 2 of AIRFA, Pub. L. No. 95-341, § 2, 92 Stat. 469, 470 (1978) (omitted from the U.S.C. as executed) provided that:

The President shall direct the various Federal departments, agencies, and other instrumentalities responsible for administering relevant laws to evaluate their policies and procedures in consultation with native traditional religious bodies in order to determine appropriate changes necessary to protect and preserve native American religious cultural rights and practices.

Compare that with the even more explicit California law:

No public agency, and no private party using or occupying public property, or operating on public property . . . shall in any manner whatsoever interfere with the free expression or exercise of Native American religion as provided in the United States Constitution and the California Constitution...."

Cal. Pub. Res. Code $\S 5097.9$ (West Supp. 1982).

In addition, various government regulations are premised precisely on the policy of protecting Native American shrine areas. For example, the Initial Report Concerning the Tennessee Valley Authority's Implementation of the Indian Religious Freedom Act of 1978, reprinted in Federal Agencies Task Force, AMERican Indian ReliGrous FrEeDOM ACT REPORT, app. B (Aug. 1979) [hereinafter cited as AIRFA REPORT] stated:

Due to incidents of vandalism and collection of artifacts by unauthorized persons, sensitive archeological sites are considered restricted areas and 
danger of that perceived conflict is that it allows the establishment clause to be employed as an excuse to ignore religious claims since special treatment to preserve a religion can be viewed as an unconstitutional establishment of religion. Because in fact there is no conflict, the establishment clause cannot be used to avoid an assessment of the validity of free exercise claims or to strike down such claims.

The Comment proposes a non-conflict approach to the religion clauses of the first amendment. That approach reflects the underlying values of the clauses and is supported by an analysis both of the political reality in which the two clauses operate and of the dangers each addresses. Briefly, free exercise claims will most often be raised to remove burdens from "minority" religions, while valid establishment clause challenges will most frequently be raised in situations in which the government has granted benefits to "majority" religions. It could be said that the free exercise clause is "pro-minority" while the establishment clause is "anti-majority."1s The religion clauses are in a relationship of logical priority - the free exercise issue must be addressed prior to the establishment issue because the former involves questions of purpose and effect that are central to reaching conclusions about the latter. ${ }^{14}$. Stated simply, government efforts to remedy a burden it has

may be fenced, posted, and patrolled for their protection. . . .

However, procedures exist by which persons may be permitted to enter a restricted area when there is a legitimate reason for their presence. These procedures . . . appear to be flexible enough to accommodate requests for access to sacred sites by practitioners of native traditional religions.

One of the National Park Service recommendations for compliance with AIRFA was to "[i]ssue regulations governing appropriate decorum, and use and protection of park resources associated with Native American traditional religious practices." Draft Assessment of Compliance Requirements of P.L. 95-341 for the National Park Service, at 7 , reprinted in AIRFA REPORT, supra. As a result of this policy, the Park Services issued regulations restricting access to the Hopi Salt Mine (an area considered sacred by the Hopi tribe) located in the Grand Canyon. National Park Service, Dep'T of the Interior, Colorado River Management Plan and Annual Operating Requirements: Grand Canyon (Dec. 1981); see also, e.g., Memorandum of the U.S. Department of Energy, Mar. 30, 1979 and the Letter from the Director of the Bureau of Land Management to the Associate Director, Indian Affairs (April 12, 1979), reprinted in AIRFA REPORT, supra, at app. B.

18 That is not to say that the establishment clause is only intended to prohibit the establishment of a national church or to prohibit the favoring of one sect over another, a position that was firmly rejected by the Supreme Court in Everson v. Board of Educ., 330 U.S. 1, 15-16 (1947) and in subsequent cases, see, e.g., McCollum v. Board of Educ., 333 U.S. 203, 210-11 (1948). Instead, this Comment argues that groups in political power are most likely to violate the establishment clause when such a violation is somehow to their own benefit; the majority group may attempt to establish its own religion or all religions but will likely not take actions that have the purpose and effect of establishing minority religions.

14 See infra notes $118-20$ and accompanying text. 
placed on the free exercise of a "minority" religion cannot realistically be viewed as having the purpose or primary effect of attempting to establish religion.

This non-conflict approach protects the right to practice a minority religion; it does not permit valid free exercise claims to be dismissed because of an illusory "conflict" with the establishment clause. Such an approach is especially justified in situations involving Indian tribes because of their long history of religious and cultural persecution and because of the nature of Indian religion itself.

Section I of this Comment describes the case at issue here. Section II discusses the views of the Supreme Court and commentators concerning the potential conflict between the two clauses. Section III shows that the two clauses, if interpreted correctly, do not conflict and that the application of the establishment clause test mandated by the Court cannot be used to strike down a free exercise claim: Section IV summarizes the conclusions of this Comment.

\section{Badoni v. Higginson}

This Comment will not directly address the merits of the free exercise claim raised in Badoni $v$. Higginson, ${ }^{16}$ but rather will argue that the court failed to consider that claim because it incorrectly perceived a conflict with the establishment clause. The interpretation of the establishment clause in this manner poses a particular threat to non-JudeoChristian religions, first, because such religious groups frequently lack access to the political process to vindicate their claims and, second, because the groups in power are often unaware of the requirements of the minority religion and the potential burdens created by government policies. ${ }^{16}$ Native American religions, because they differ in basic respects

15638 F.2d 172, $174-76$ (10th Cir. 1980), cert. denied, 452 U.S. 954 (1981).

16 Unfortunately this ignorance of the nature of Indian religions was apparent in the district court decision in Badoni, 455 F. Supp. 641 (D. Utah 1977). The court there stated that the plaintiff's interests were not "deep religious conviction[s], shared by an organized group and intimately related to daily living." Id. at 645 (quoting Wisconsin v. Yoder, 406 U.S. 205, 214 (1972)). This finding was based on the fact that "the medicine men who allegedly conduct the religious rights . . . are not recognized by the Navajo Nation as such. Also, the training of these medicine men has not been tribally organized or carried out, and took place years ago." The court further argued that, because the ceremonies at Rainbow Bridge were held infrequently and sporadically, the Monument did not have "anything approaching deep, religious significance." An attempt by counsel to explain that the "Navajo ceremonies . . . are not periodic ceremonies ... [but] are performed when needed, and requested by an individual or family," was dismissed as insufficient by the court. Id. at 645-46. The ethnocentrism of the court's opinion hardly needs to be pointed out. The Tenth Circuit ignored this finding and simply assumed the validity of the religious interests. Badoni, $638 \mathrm{~F} .2 \mathrm{~d}$ at 177 n.4. 
from Western religions, ${ }^{17}$ are particularly susceptible to such infringements. ${ }^{18}$

Recent free exercise claims raised by Indians have involved disputes over government regulations permitting the desecration of sacred areas now under government control. Several major lawsuits have been brought, including the one discussed in this Comment, since the enactment of the American Indian Religious Freedom Act (AIRFA), which recognized the protection of shrines as an area of specific concern. ${ }^{19}$ In

17 Indian tribes lack the distinctions present in Western societies between religion and culture or between the religious and the secular. For a discussion of the symbiotic relationship between Native American religion and culture, see Note, Native Americans and the Free Exercise Clause, 28 Hastings L.J. 1509, 1510 (1977). The religions are not "commemorative"-they do not memorialize past events (such as a founding) and do not incorporate a set of established truths, dogmas, and creeds. Instead they are based on the perpetuation of rituals and ceremonies, each with a specific purpose. The ceremonies are to be performed in a set manner, often at a particular location, and any alterations can bring great harm to the well-being of the people. AIRFA REPORT, supra note 12 , at 10 . The rituals, and in fact the entire religion, are closely tied to sacred places and substances and to the land: The destruction of a sacred site harms not only the Indian religion, but the community and culture as well, and such actions can cause a serious disorientation of the society. For a general discussion of the nature of Native American religions and the relationship to sacred areas, see NIYC Announcer, Indian Religious Freedorn Campaign, printed in AMERICANS BEFORE ColumBus: A Publication of The National Indian Youth Council, Special Edition (Spring 1982), at 1 [hereinafter cited as NIYC Jourmal].

${ }_{18}$ Indian religion cases have most commonly involved free exercise claims over the use of peyote and protected species in religious rituals and over the wearing of long hair as an expression of religious belief. Several state courts have exempted Native American religion from the general restrictions on peyote use. E.g., State v. Whittingham, 19 Ariz. App. 27, 504 P.2d 950 (1973), cert. denied, 417 U.S. 946 (1974); People v. Woody, 61 Cal. 2d 716, 394 P.2d 813, 40 Cal. Rptr. 69 (1964). In the hair length controversies, most of which arose in the context of prisons or schools, the lower courts have been divided, often over the problem of what constitutes a "religious" practice and over the extent of first amendment protection given to hair length. Compare New Rider v. Board of Educ., 480 F.2d 693 (10th Cir.) (rejecting free speech and free exercise arguments concerning the wearing of long hair in school), cert. denied, 414 U.S. 1097 (1973) with Teterud v. Burns, 522 F.2d 357 (8th Cir. 1975) (accepting a free exercise argument concerning the wearing of long hair by Indian prisoners).

The protected species cases have involved the use of animals and animal parts essential to Native American religious ceremonies. The killing of these animals is often either regulated by the government or directly forbidden because they are endangered species. See, e.g., Frank v. Alaska, 604 P.2d 1068 (Alaska 1979) (moose found to be central to religious ritual). For a discussion of the protected species cases, see Note, supra note 17, at 1530-33. The problem of federal restrictions on the use of substances, including both peyote and protected species, was specifically mentioned as an area of concern in the House Report accompanying AIRFA, H.R. REP. No. 1308, 95th Cong., 2d Sess. 2-3 (1978); see also 124 Cong. Rec. 21,444 (1978) (remarks of Rep. Udall). In all of these areas there have been inconsistencies among the jurisdictions, often based on the questions of what constitutes a religion and what criteria should be used to balance individual interest in free exercise against state interest in regulation. Note, supra note 17 , at 1534.

19 See H.R. REP. No. 1308, 95th Cong., 2d Sess. 1-3 (1978); AIRFA RePORT, supra note 12, at 13; 124 CoNG. REC. 21,444 (1978) (remarks of Rep. Udall). 
all of these suits, the Indian religion claims were struck down. ${ }^{20}$

Badoni v. Higginson ${ }^{21}$ involved allegations by individual members of the Navajo Tribe, and by three chapters of the Navajo Nation, ${ }^{22}$ that the operation of Glen Canyon Dam, built pursuant to congressional authorization, violated plaintiffs' rights under the free exercise clause of the first amendment. ${ }^{23}$ After completion of the dam in 1963, water backed up behind the dam, forming Lake Powell, and by 1970 the lake entered the Rainbow Bridge National Monument, a 160 acre tract of federally owned land which is surrounded by the Navajo reservation. Within the National Monument is Rainbow Bridge, a great sandstone arch 309 feet high, which, along with a nearby spring and prayer spot, has, central importance to the religious beliefs of the Navajo. ${ }^{24}$

By 1977, the water was over twenty feet deep directly under the Bridge. Prior to the creation of Lake Powell, the Bridge had been in a relatively inaccessible and deserted area. The creation of the lake provided access to the Monument, and tourists began to visit on tour boats and private pleasure boats, encouraged by government construction of docking facilities near the Bridge. ${ }^{25}$ The plaintiffs believed that if humans altered the earth in the area of the Bridge, plaintiffs' prayers would not be heard by the gods and their ceremonies would be ineffective in preventing evil and disease. ${ }^{28}$ The court found that the development interfered with the practice of the Navajo religion: "Tourists visiting the sacred area have desecrated it by noise, litter and defacement of the Bridge itself. Because of the flooding and the presence of tourists, plaintiffs no longer hold ceremonies in the area of the Bridge."27

Under the free exercise aspect of the suit, the plaintiffs claimed that, by allowing and encouraging tourists to visit the area, the government had permitted desecration of a sacred spot and prevented the

Recently, the recognition of the urgency of the still existing threat to Native American religions has spurred efforts by the National Indian Youth Council (NIYC) to begin a nationwide campaign for American Indian Religious Freedom. Among the most prominent goals of the campaign are efforts to preserve Indian sacred sites on federal land and to support the rights of Indians to worship free of intrusion at their traditional sites. NIYC Journal, supra note 17, at 1-3.

${ }^{20}$ See Sequoyah v. T.V.A., 620 F.2d 1159 (6th Cir. 1980); Crow v. Gullet, 541 F. Supp. 785 (D.S.D. 1982); Hopi Indian Tribe v. Block, No. 81-0481 (D.D.C. June 12, 1981) (available Dec. 1, 1982, on LEXIS, Genfed Library, Dist file).

22638 F.2d 172 (10th Cir. 1980), cert. denied, 452 U.S. 954 (1981).

22 Id. at 175.

${ }^{2 s} I d$. at $175-76$.

24 Id. at 177.

25 Id.

20 Id. at 175.

${ }^{27}$ Id. at 177. 
plaintiffs from performing their rituals. ${ }^{28}$ They requested that the government take-steps-such as prohibiting consumption of beer at the Monument-to prevent desecration of the area, and they further requested the government to close "the Monument on reasonable, notice when religious ceremonies are to be held there."29

The court denied both requests. While admitting the difficulty of performing sacred ceremonies when surrounded by tourists, ${ }^{30}$ the court asserted that any government corrective action would be a violation of the establishment clause: "What plaintiffs seek in the name of the Free Exercise Clause is affirmative action by the government which implicates the Establishment Clause of the First Amendment." 31 The court then applied the establishment clause test mandated in School District of Abington $v$. Schemp $p^{32}$ which specifies that government action does not violate the establishment clause if the purpose and primary effect of the action are secular and neither advance nor inhibit religion. ${ }^{38}$ Using this analysis, the court concluded that the "[i]ssuance of regulations to exclude tourists completely from the Monument for the avowed purpose of aiding plaintiffs' conduct of religious ceremonies would seem a clear violation of the Establishment Clause."34

${ }^{28}$ Id. at 176. As noted previously, Indian religions are centered around the performance of rituals which must be done in a strictly specified manner and only with appropriate participants. See supra note 17.

20638 F.2d at 178.

so "We are mindful of the difficulties facing plaintiffs in performing solemn religious ceremonies in an area frequented by tourists." Id.

31 Id.

32374 U.S. 203, 222 (1963).

s3 $I d$.

s4 638 F.2d at 179.

Badoni became an unfortunate example for the plaintiffs in Hopi Indian Tribe v. Block, No. 81-0481 (D.D.C. June 12, 1981) (available Dec. 1, 1982, on LEXIS, Genfed library, Dist. file). In that case, plaintiffs sued to prevent the federal government from authorizing any further development of recreation facilities known as the Arizona Snow Bowl in the Coconino National Forest in Arizona, an area that included the San Francisco Peaks. Plaintiffs claimed that the operation and expansion of the recreational facilities constituted "a violation of the plaintiffs' First Amendment guarantee of free exercise of religion due to the sacred nature of the mountains and their centrality to both the Hopi and Navajo religions." Hopi Indian Tribe, slip op. at 2.

The nature of this claim was somewhat unusual, as the government did not prohibit plaintiffs' religious exercises in the area of the Peaks nor deny them access to the Peaks for purposes of gathering sacred substances. Instead, the claim was based on the harm done to the religion through the desecration of a sacred area. The court rejected this as a cognizable first amendment harm and claimed further that to recognize such a claim "would clearly fly in the fact [sic] of the principles of the Establishment Clause of the First Amendment." Id. at 6. Again, the court applied a version of the establishment clause test requiring a law: (1) to reflect a clearly secular purpose, (2) to have a primary effect that neither advanced nor inhibited religion, and (3) not to excessively entangle the government in religious affairs. Id. at 6-7. The court viewed the discontinuance of development in the Snow Bowl area as an action that would have a primarily 
It is this last aspect-the use of the establishment clause to avoid reaching the free exercise claim-that is the focus of this Comment. ${ }^{35}$

religious purpose and effect and concluded that "[t]he plaintiffs do not have a constitutional right under the First Amendment to require that the government manage this property as a religious shrine for them; not only is it not required by the First Amendment, but it is clearly prohibited by the Establishment Clause." Id. at 7. The claim under the AIRFA was also rejected because the court held that the AIRFA only required agencies to "evaluate their policies and procedures with the aim of protecting Indian religious freedoms . . . Here, the defendants have clearly complied with this mandate." Id. at 8 (emphasis added).

Compare Badoni and Hopi Indian Tribe with Sequoyah v. T.V.A., 620 F.2d 1159 (6th Cir. 1980), where the court assessed the suit solely on the basis of the free exercise claim and denied the legitimacy of that claim and Northwest Indian Cemetery Protective Ass'n v. Peterson, 565 F. Supp. 586, 597 (N.D. Gal. 1983) ("Actions compelled by the Free Exercise Clause do not violate the Establishment Clause.").

3s The free exercise claim in itself is worthy of exploration, although it is beyond the boundaries of this Comment. The claim involved the assertion by a religious group of the exclusive right to use government resources set aside for the general public. Although the government is willing to share these resources with the Native American religion, the land development in itself desecrates a holy site and the entrance of the general public violates the privacy assertedly needed to perform sacred rituals. Those claims seem strong, given the Indians' prior possession and use of the land and the possibly unconstitutional original taking of a sacred shrine. It is a more doubtful question whether a religious group could lay claim to government land based on an occurrence that made the land holy after the government had legally acquired it. The standard for evaluating a free exercise claim was recently reiterated in United States v. Lee, 455 U.S. 252, 257 (1982) ("The state may justify a limit on religious liberty by showing that it is essential to accomplish an overriding governmental interest.").

It is conceivable of course that such analysis was done silently in Badoni and that a decision was reached that government interests outweighed the preservation of the religious liberty of a minority. But such silent analysis under the guise of constitutional authority is undesirable.

If the court had decided the case on the merits of the free exercise claim, several scenarios would have been possible. Had the court ruled that there was no infringement, the tribe would be free to bring later suits based on subsequent and possibly more severe incidents of infringement. Other Indian tribes in different circumstances could still bring suit and realistically hope that the courts would remedy any serious burdens on their religion. On the other hand, had the court decided that there was an infringement, but one justified by a compelling government interest, the tribe could then appeal to the public, lobby Congress, or form coalitions pressuring the government to reassess its priorities. (In a sense there is evidence that Congress had already performed this evaluation and decided in favor of Indian freedom of religion. See supra note 12.) But since the court found that the establishment clause forbids adjustments to the Indians' requests, it foreclosed (for the Navajo and other tribes) further legal or political recourse. In fact, the decision could be read to suggest that any government accommodations already made to native religion are unconstitutional. The Badoni court stated:

Plaintiffs cite the Park Service's proposed guidelines for use of Grand Canyon National Park, which prohibit entry on certain sacred Indian religious sites. They also cite the American Indian Religious Freedom Act ... But we do not have before us the constitutionality of those laws or regulations or of any action taken by defendants in alleged violation of them. 
That constitutional "blockade" of the free exercise claim suggests there is no recourse for the religious minority to the political process since any government action to remove impediments to the religious practices of the Navajo people could be viewed as a constitutional violation. In fact, it could well be argued that congressional and agency actions taken to protect Indian religious freedom have already violated the establishment clause.

Badoni, then, is the starting point for investigating the relationship between the religion clauses of the first amendment.

\section{The Perceived Conflict Between the Religion Clauses}

\section{A. The Viewpoint of the Court}

Both the Supreme Court and commentators have criticized the inconsistency and murkiness of the decisions analyzing the religion clauses of the first amendment. "[T]he line of separation [of church and state], far from being a 'wall,' is a blurred, indistinct, and variable barrier depending on all the circumstances of a particular relationship."36 That inconsistency has been blamed both on the language of the religion clauses ${ }^{37}$ and on the tendency of the Justices to issue statements of unwarranted breadth. ${ }^{38}$

The inconsistency is particularly marked when the Court addresses the "conflict" or "tension" between the free exercise and the establishment clauses. That conflict is most frequently perceived when the government exempts religious groups from laws of general applicability (such as unemployment requirements, compulsory education, etc.). These exemptions, required by the free exercise clause, are sometimes viewed as a violation of the establishment clause of the first amendment. The Court and individual Justices have taken three separate and contradictory viewpoints on the relationship between the two clauses: (1) there is no conflict; (2) the two clauses conflict, but that conflict is resolved in favor of the establishment clause; and (3) the conflict is resolved in favor of the free exercise clause.

${ }^{36}$ Lemon v. Kurtzman, 403 U.S. 602, 614 (1971).

s7 Id. at 612.

ss "The considerable internal inconsistency in the opinions of the Court derives from what, in retrospect, may have been too sweeping utterances on aspects of these clauses that seemed clear in relation to the particular cases but have limited meaning as general principles." Walz v. Tax Comm'n, 397 U.S. 664, 668 (1970). See also Kurland, Of Church and State and the Supreme Court, 29 U. CHI. L. REv. 1, 96 (1961); infra note 40 and accompanying text. 


\section{No Conflict}

An explicit statement of the no conflict approach came from Justice Rutledge in his dissent in Everson v. Board of Education: "Establishment' and 'free exercise' were correlative and coextensive ideas, representing only different facets of the single great and fundamental freedom."39 More recently, Justice Rehnquist criticized the Court for having created the tension between the clauses through unnecessarily broad interpretations. He suggested that a narrow reading of the clauses would eliminate any perceived conflict. ${ }^{40}$ The difference between the non-conflict approach this Comment will suggest and Justice Rehnquist's non-conflict approach is that the former does not require a narrow interpretation of the freedoms secured by the free exercise clause. $^{41}$

In certain instances, the Court has appeared to recognize a potential conflict, but then dismissed it as nonexistent, without expressly discussing whether such conflicts do in fact exist or how they are to be handled. For example, in Sherbert $v$. Verner, the Court simply stated that the exemption from unemployment compensation requirements granted to a Seventh-Day Adventist did not foster "the 'establishment" of the Seventh-Day Adventist religion." 42

One commentator has suggested that in various cases the Court avoids the issue of conflict without ever resolving it. ${ }^{43} \mathrm{He}$ cites as an example Walz v. Tax Commission, ${ }^{44}$ a case in which the Court held that tax exemptions for churches did not violate the establishment clause without reaching the question of whether free exercise mandated

s9 330 U.S. 1,40 (1947).

40 Although the Court ... recognizes the "tension" between the two Clauses, it does little to help resolve that tension or to offer meaningful guidance to other courts which must decide cases like this on a day-by-day basis. Instead, it simply asserts that there is no Establishment Clause violation here and leaves the tension between the two Religion Clauses to be resolved on a case-by-case basis. . . . I believe that the "tension" is largely of this Court's own making, and would diminish almost to the vanishing point if the Clauses were properly interpreted.

Thomas v. Review Bd., 450 U.S. 707, 722 (1981) (Rehnquist, J., dissenting).

Justice Rehnquist went on to suggest that the free exercise clause should not be applied to indirect burdens, $i d$. at 722-23, while the establishment clause should not invalidate "governmental assistance which does not have the effect of 'inducing' religious belief, but instead merely 'accommodates' or implements an independent religious choice. . . " Id. at 727. See also Sherbert v. Verner, 374 U.S. 398, 414-17 (1963)

(Stewart, J., concurring).

41 See supra note 40; infra notes 77-137 and accompanying text.

42 Sherbert v. Verner, 374 U.S. 398, 409 (1963).

4s Pfeffer, Freedom and/or Separation: The Constitutional Dilemma of the First Amendment, 64 MiNN. L. REv. 561, $571-75$ (1980).

44397 U.S. 664 (1970). 
such exemptions. In TWA, Inc. v. Hardison, ${ }^{45}$ the Court was called upon to decide the constitutionality of legislation requiring employers to make reasonable accommodations to the religious needs of their employees. ${ }^{18}$ The Court failed to reach the question of whether Congress could pass provisions to protect free exercise without violating the establishment clause, and instead decided the matter on statutory grounds. ${ }^{47}$

\section{Conflict Resolved in Favor of the Establishment Clause}

Several defendants in establishment clause cases have advanced the argument that denial of aid to religion violates free exercise. Such a claim was made in Committee for Public Education v. Nyquist, ${ }^{48}$ in which the Court held unconstitutional a law providing tuition grants for students attending church schools. The Court rejected the claim that tuition grants were necessary to promote the free exercise of religion, stating that "this Court repeatedly has recognized that tension inevitably exists between the Free Exercise and the Establishment clauses ... and that it may often not be possible to promote the former without offending the latter." $" 49$

Similarly, in School District of Abington $v$. Schempp, ${ }^{50}$ the Court struck down state-mandated school prayer as violative of the establishment clause, despite the claim that the law protected the free exercise of the majority: "While the Free Exercise Glause clearly prohibits the use of state action to deny the rights of free exercise to anyone, it has never meant that a majority could use the machinery of the State to practice its beliefs." ${ }^{\prime 31}$

Justice Stewart, in his concurrence in Sherbert v. Verner, was highly critical of the Court's interpretation of the establishment clause in cases such as Schempp. He argued that "legitimate claims under the

45432 U.S. 63 (1977).

48 Two other reasonable accommodation employment cases have reached the Supreme Court since 1970 . Both were affirmed by an equally divided Court with no written opinion and thus have little precedential value. See Cummins v. Parker Seal Co., 516 F.2d 544 (6th Cir. 1975), affd per curiam by an equally divided Court, 429 U.S. 65 (1976), vacated, 433 U.S. 903 (1977), rev'd on statutory grounds, 561 F.2d 659 (6th Cir. 1977) (per curiam) (The Sixth Circuit reversed its earlier holding to conform with the statutory interpretation in TWA, Inc. v. Hardison, 432 U.S. 63 (1977)); Dewey v. Reynolds Metals Co., 429 F.2d 324 (6th Cir. 1970), affd per curiam by an equally divided Court, 402 U.S. 689 (1971).

47432 U.S. at 70.

48413 U.S. 756 (1973).

19 Id. at 788.

so 374 U.S. 203 (1963).

s1 Id. at 226. 
Free Exercise Clause will run into head-on collision with the Court's insensitive and sterile construction of the Establishment Glause." Stewart reasoned that under such construction, the establishment clause required the state to deny the claim for unemployment compensation when the refusal to work was based on a religious creed. ${ }^{53}$ In effect, he argued, the Court had backed itself into a position where the establishment clause required the denial of legitimate free exercise claims.

\section{Conflict Resolved in Favor of the Free Exercise Glause}

In contrast to the previous two positions, the Court, when addressing free exercise claims, has frequently held that the elimination of a burden on free exercise (such as the creation of an exemption from a law of general applicability) does not "establish" religion, despite the "benefit" to the religious individual." Individual Justices have suggested that when a conflict does exist, the free exercise claim must dominate. ${ }^{\text {Sb }}$ They cite a number of situations in which denying benefits to religion would be considered a violation of free exercise, such as the provision of chaplains in the military and in prisons, religious services in federal hospitals, and school lunches provided to private as well as public school students. ${ }^{5 B}$ Often this viewpoint is expressed as one of "accommodation" of government to religion, an accommodation which "can hardly be characterized as sponsorship or active involvement," but which " "reflects nothing more than the governmental obligation of neutrality in the face of religious differences, and does not represent that involvement of religious with secular institutions which it is the object of the Establishment Clause to forestall." "s7 Such an accommodation is

62374 U.S. 398, 414 (1963) (footnote omitted).

os Id. at 415 .

of See Thomas v. Review Bd., 450 U.S. 707, 719 (1981), where the Court held that the state could not deny unemployment benefits to a Jehovah's Witness who quit his job because his religion forbade participation in the production of armaments. The Court considered and rejected the suggestion that such an exemption might violate the establishment clause and stated that the "benefit" to Thomas manifested nothing more "than the tension between the two Religious Clauses which the Court resolved in Sherbert."

Bs "[T]he logical interrelationship between the Establishment and Free Exercise Clauses may produce situations where an injunction against an apparent establishment must be withheld in order to avoid infringement of the rights of free exercise." School Dist. of Abington v. Schempp, 374 U.S. 203, 247 (1963) (Brennan, J., concurring). See also id. at 295 (Brennan, J., concurring); TWA, Inc. v. Hardison, 432 U.S. 63, 90 (1977) (Marshall, J., dissenting).

so See School Dist. v. Schempp, 374 U.S. 203, 296-98 (1963) (Brennan, J., concurring); Engel v. Vitale, 370 U.S. 421, 437 n.1 (1962) (Douglas, J., concurring).

${ }_{57}$ Wisconsin v. Yoder, 406 U.S. 205, 234 n.22 (1972) (quoting Sherbert v. Verner, 374 U.S. 398, 409 (1963)). See also Zorach v. Clauson, 343 U.S. 306, 313-14 (1952) (implying that failure of the schools to permit release time for religious instruc- 
viewed as necessary to insure that government "neutrality" to religion does not become government hostility to religion. ${ }^{\mathbf{5 8}}$

The accommodation theory recognizes the necessary interrelationship between government and religion and permits government to accommodate its institutions and programs to the religious interests of the people. $^{89}$ Most often accommodation is required when laws of general applicability conflict with the free exercise of religious minorities. ${ }^{60}$ In such situations, accommodation or "free exercise neutrality" is said to permit and even require "the state to make special provision for religious interests in order to relieve them from both direct and indirect burdens placed on the free exercise of religion by increased governmental regulation." Verner, ${ }^{62}$ in which the Court exempted a Seventh-Day Adventist from the requirement that she be available for work on Saturday in order to qualify for unemployment compensation. The Court stated that such accommodation does not violate the establishment clause because "the extension of unemployment benefits to Sabbatarians in common with Sunday worshippers reflects nothing more than the governmental obligation of neutrality in the face of religious differences."63 In fact, the Court found such accommodation to be not only permissible under the establishment clause, but to be positively required by the free exercise clause. ${ }^{64}$

tion might be a free exercise violation and that the government must "accommodate" spiritual needs). In Walz v. Tax Comm'n, the Court referred to this accommodation as a kind of "benevolent neutrality which will permit religious exercise to exist without sponsorship and without interference." 397 U.S. at 669.

s8 Schempp, 374 U.S. at 306 (Goldberg, J., concurring); Zorach v. Clauson, 343 U.S. 306, 312 (1952).

so See, e.g., Zorach, in which the Court upheld a New York law permitting public schools to release pupils during school hours to attend religious instruction elsewhere. For a general discussion of accommodation theory, see P. KAUPER, RELIGION AND THE Constitution 67-75 (1964).

oo See, e.g., Sherbert v. Verner, 374 U.S. 398 (1963), in which the Court held that a state unemployment compensation law must accommodate those whose religious beliefs prevented them from working on Saturdays.

o1 Giannella, Religious Liberty, Nonestablishment, and Doctrinal Development: Part II. The Nonestablishment Principle, 81 HaRv. L. Rev. 513, 518 (1968) [hereinafter cited as Giannella II].

62374 U.S. 398 (1963).

os Id. at 409.

os Id. at 410 ("Our holding today is . . that South Carolina may not constitutionally apply the eligibility provisions so as to constrain a worker to abandon his religious convictions respecting the day of rest."). See also id. at 415-16 (Stewart, J., concurring). 


\section{B. The Viewpoint of the Commentators}

Various attempts have been made by commentators to develop a coherent theory that would explain the relationship between the two religion clauses. One group of commentators asserts that a conflict between the two clauses, not likely perceived by the framers of the first amendment, does exist, and has been exacerbated by increased government action in areas of individual life. ${ }^{68}$ Once the conflict is admitted, the clauses must then be reconciled. Both Giannella and Tribe assert that the free exercise clause is supreme. ${ }^{66}$ They believe that actions that are " 'arguably compelled' by free exercise" do not violate the establishment clause. ${ }^{67}$ The state is permitted and sometimes required to make special provision for religious interests to relieve them from burdens of government regulation ("free exercise neutrality") and the establishment clause does not compel exclusion of religious activities and associations from regulation when secular purposes justify inclusion ("political neutrality") ${ }^{88}$ Thus, religious associations must be given police and fire protection equal to other voluntary associations, because exclusion would be a form of government hostility to religion. ${ }^{69}$

Alternatively, several commentators agree that a conflict exists, but argue that free exercise is supreme on the principle of "religious liberty" that underlies both clauses. ${ }^{70}$ That position is similar to the

es Giannella, Religious Liberty, Nonestablishment, and Doctrinal Development: Part I. The Religious Liberty Guarantee, 80 HARv. L. REv. 1381, 1389 (1967) [hereinafter cited as Giannella I]. Justice Rehnquist, in his dissent in Thomas v. Review Bd., 450 U.S. 707 (1981), also asserted that the tension between the two clauses is of relatively recent vintage and is at least in part an outgrowth of the recent increase in social welfare legislation. Id. at 720-21.

6o Giannella bases his argument on the perception that free exercise is premised on a vital civil right while the establishment clause is premised on an outmoded eighteenth century political theory. Giannella I, supra note 65 , at 1389 . Tribe argues that the supremacy of the free exercise claim "is the natural result of tolerating religion as broadly as possible rather than thwarting at all costs even the faintest appearance of establishent." L. TRIBE, American Constitutional LAW § 14-7, at 833 (1978). His argument is premised, at least in part, on the value of encouraging religious diversity and pluralism, and a commitment to the "flourishing of conscience." Id. $\S 14-7$, at 834 .

or L. TRIBE, supra note $66, \S 14-4$, at 822 .

os Giannella II, supra note 61, at 518-19.

Id. at 519-22.

70 "A useful starting point is to recognize that religious liberty-broadly conceived to include all varieties of religious belief and freedom of total belief and nonbelief-is the central value served by both clauses. Whatever else government may or may not do, it is required to respect religious liberty. This means, first of all, that it must refrain from laws that restrict the free exercise of religion or which discriminate on religious grounds in the granting of rights or privileges, unless clearly defined policy grounds warrant such discrimination."

P. KAUPER, supra note 59, at 77. See also Katz, Freedom of Religion and State Neu- 
Court's "accommodation" approach: "An accommodation theory . . . recognizes that any principle of no-aid or neutrality derived from the establishment limitation must yield in order to assure the full enjoyment of religious liberty or to permit the legislature a discretionary authority to implement this liberty."71

A second major group of commentators argues that any conflict between the religion clauses is illusory. Kurland has stated that the two clauses should be read "as a single precept that government cannot utilize religion as a standard for action or inaction because these clauses prohibit classification in terms of religion either to confer a benefit or to impose a burden."72 Kurland's strict neutrality approach, not generally accepted by the Court, would permit government to confer benefits on religion as long as the benefits were part of a classification scheme that naturally included religion within its boundaries, such as police and fire protection. ${ }^{73}$ Exemptions from laws of general applicability, however, would be difficult to uphold since those exemptions would be based on a religious classification.

Pfeffer argues forcefully for a unitary approach to the first amendment, each clause requiring and protecting the other: "Nothing in American constitutional history or tradition justifies an apportionment of values between disestablishment and freedom or indeed the dichotomy itself. The struggle for religious liberty and for disestablishment were parts of the same single evolutionary process that culminated in the First Amendment."74 The apparent conflicts between the two clauses are generally conflicts within free exercise itself-between free exercise and government regulation. ${ }^{75}$

trality, 20 U. GHI. L. REv. 426, 428, 432-33 (1953).

71 P. KAUPER, supra note 59 , at 71 .

72 Kurland, supra note 38, at 5-6.

73 Justice Harlan, concurring in Walz, 397 U.S. at 696, viewed this neutrality principle as requiring an equal protection mode of analysis. Legislation that incidentally benefitted religion was valid if the class benefitted was so broad that religion fell within its natural perimeters. (The Court in Walz upheld the validity of state property tax exemptions for charitable organizations that included churches.)

7* L. Pfeffer, Church, State and Freedom 122 (1953).

75 For example, the supporters of aid to parochial schools maintain that such aid is required by the free exercise clause since poor families must send their children to public school and will therefore have to forego the religious training they wish their children to receive. Opponents maintain that such aid would violate the establishment clause. This apparent conflict, however, is not one of competing constitutional values-that is, constitutionally mandated support versus constitutionally forbidden support-but rather is between constitutionally mandated free exercise and statutorily mandated compulsory attendance laws. "[T]he conflict is not between nonestablishment and free exercise, but rather exclusively within the area of free exercise. Resolution of that conflict might require the Court to hold that compulsory school attendance laws are unconstitutional ... but it would in no way require state support of parochial 


\section{Summary}

While the Supreme Court has frequently interpreted the establishment clause in a manner that accommodates the demands of free exercise, it has done so without providing a coherent theory of precisely how the clauses are to be related. Most commentators have attempted to reconcile the clauses by looking for underlying themes and accommodation between the two clauses, tending toward the supremacy of the free exercise clause in the face of an alleged establishment violation.

It is the thesis of this Comment that a non-conflict approach is the most appropriate way to unify the clauses, and furthermore that such an approach is consistent with a liberal reading of the free exercise clause's protection of religion. That approach can be assimilated under current establishment clause doctrine and the three-part test mandated by the Court, ${ }^{78}$ and is justifiable as upholding the underlying purposes of the establishment clause.

\section{Non-Conflict Approach to the Religion Clauses}

\section{A. Rationale for the Non-Conflict Approach}

The following discussion will first examine the underlying values of the establishment clause and demonstrate that the correction of a free exercise infringement does not adversely affect these values. The Comment will then show that the two clauses are intended to respond to different types of dangers which might result from a failure of the political process to protect freedom of religion, so that when one danger is corrected (the burden on the "minority"), the second will not occur (undue benefit to the "majority"). Finally, the Comment will show that the clauses are in a relationship of logical priority-the free exercise analysis is a prerequisite for determining whether the purpose and effect of government action impermissibly violate the establishment clause.

\section{The Underlying Purposes of the Establishment Clause}

There is some consensus of opinion that the original purposes of the establishment clause were quite narrow - to prevent Congress from interfering with state establishments of religion, and to guard against the establishment of a national church or sect with the concomitant per-

schools." Id. at 575.

76 See infra note 118 and accompanying text. 
secution of religious minorities. ${ }^{77}$ By the same token, however, there is an equal consensus that such historical understandings of the establishment clause are no longer useful in an era in which government intrudes more and more into individual life, and in which the number and diversity of religious minorities have increased dramatically. ${ }^{\mathbf{7 8}}$

The Court, for the past fifty years, has given a broad interpretation to the purposes of the establishment clause.

The "establishment of religion" clause of the First Amendment means at least this: Neither a state nor the Federal Government can set up a church. Neither can pass laws which aid one religion, aid all religions, or prefer one religion over another. . . . In the words of Jefferson, the clause against establishment of religion by law was intended to erect "a wall of separation between church and state."7ө

While this ringing statement of the strict separation or no-aid theory has been tempered into the accommodation approach, ${ }^{80}$ the Court consistently has reiterated the view that the establishment clause forbids more than just the establishment of a single sect, but rather is directed toward any undue involvement of government with religion. ${ }^{81}$ Underlying this view are the central values inherent in the establishment clause. That clause protects religious freedom of choice, proscribing all govern-

77 See P. KAUPER, supra note 59, at 46; Zorach v. Clauson, 343 U.S. 306, 319 (1952)(Black, J., dissenting); Everson v. Board of Educ., 330 U.S. 1, 8-10 (1947). But compare Justice Rutledge's dissent in Everson where he states that the purpose of the establishment clause was "not to strike merely at the official establishment of a single sect, creed or religion. It was to create a complete and permanent separation of the spheres of religious activity and civil authority by comprehensively forbidding every form of public aid or support for religion." 330 U.S. at 31-32.

${ }_{78}$ See Brennan's concurrence in Schempp for an analysis of why "[a] too literal quest for the advice of the Founding Fathers" is both "futile and misdirected." 374 U.S. at 237 (Brennan, J., concurring); see also Giannella I, supra note 65, at 1383.

70 Everson v. Board of Educ., 330 U.S. 1, 15-16 (1947).

80 In fact, the Court itself in Everson allowed the challenged aid (reimbursement for bus transportation to parochial schools), thus indicating that the strict no-aid theory may have been no more than a rhetorical device. This inconsistency prompted Justice Jackson's famous quote:

In fact, the undertones of the opinion, advocating complete and uncompromising separation of Church from State, seem utterly discordant with its conclusion yielding support to this commingling in educational matters. The case which irresistibly comes to mind as the most fitting precedent is that of Julia who, according to Byron's reports, "whispering 'I will ne'er consent," -consented."

330 U.S. at 19 (Jackson, J., dissenting).

81 See, e.g., School Dist. of Abington v. Schempp, 374 U.S. 203, 219 (1963); McGowan v. Maryland, 366 U.S. 420, 442 (1961); McCollum v. Board of Educ., 333 U.S. 203, 211 (1948). 
ment favoritism in matters of belief and religious expression, and prevents government from aiding religion in any way that would give religious belief the imprimatur of government (and have a corrupting effect on individual matters of conscience). ${ }^{82}$ The advance of a religion should come only from the voluntary support of its followers; there should be a free competition of faiths to promote the diversity desirable in our society. ${ }^{83}$ Thus, government may neither directly legislate matters of belief nor indirectly utilize " 'the prestige, power, and influence' of a public institution to bring religion into the lives of citizens."

For the framers, establishment "connoted sponsorship, financial support and active involvement of the sovereign in religious activity." The modern understanding is somewhat broader. In general, there can be no undue involvement of government with religion, an involvement measured by the impact government participation has on freedom of belief and conscience, ${ }^{88}$ by the danger of government placing an official stamp of approval on religion, ${ }^{87}$ or, in particular, by the threat of political divisiveness and strife along religious lines. ${ }^{88}$ The establishment clause seeks to prevent any entanglement of church and state that would tend to "destroy government and degrade religion."

If those are the underlying values of the establishment clause, ${ }^{80}$ and the dangers to be avoided are government coercion of religious belief and excessive government entanglement with the working of reli-

82 See Giannella II, supra note 61, at 517; McGowan v. Maryland, 366 U.S. 420, 466 (1961) (The establishment clause proscribes government legislation in the area of "man's belief or disbelief in the verity of some transcendental idea and man's expression in action of that belief or disbelief.").

ss See L. TRIBE, supra note 66, § 14-3, at 818; Giannella II, supra note 61, at 517; see also School Dist. of Abington v. Schempp, 374 U.S. 203, 228-29 (1963) (Douglas, J., concurring).

st Walz v. Tax Comm'n, 397 U.S. 664, 696 (1970) (Harlan, J., concurring). See also Engel v. Vitale, 370 U.S. 421, 431 (1962) (government power, prestige, and financial support placed behind religion can exert indirect coercive pressure on religious minorities); McCollum v. Board of Educ., 333 U.S. 203, 227 (1948) (Justice Frankfurter discusses the impermissibility of having religious instruction on school property during school hours because of the danger of the power and prestige of the school being linked with religious training.).

os Walz v. Tax Comm'n, 397 U.S. 664, 668 (1970).

B. KAUPER, supra note 59, at 77-78.

s7 See Engel v. Vitale, 370 U.S. 421, 429 (1962).

* Larkin v. Grendel's Den, Inc., 103 S. Ct. 505, 512 (1982); Lemon v. Kurtzman, 403 U.S. 602, 622-23 (1971); Walz v. Tax Comm'n, 397 U.S. 664, 694, 698 (1970) (Harlan, J., concurring); Everson v. Board of Educ., 330 U.S. 1, 53 (1947) (Rutledge, J., dissenting); Gianella II, supra note 61, at 517.

so Engel v. Vitale, 370 U.S. 421, 431 (1962); Note, Toward a Constitutional Definition of Religion, 91 HARV. L. REv. 1056, 1058-59 (1978).

70 For views of various commentators on these values, see L. TRIBE, supra note 66 , § 14-3, at 818; Giannella II, supra note 61 , at 517 ; Note, supra note 89 , at 1058 59. 
gion, then the correction of an impermissible infringement on free exercise will not only not create or exacerbate those dangers, but will affirmatively foster the values underlying the establishment clause. By definition, when a free exercise violation has occurred (a significant burden on the religion unjustified by a compelling state interest), ${ }^{81}$ the government has already impermissibly involved itself with religion in a manner coercive of religious freedom. In Badoni $v$. Higginson, ${ }^{92}$ the Navajos were prevented by government action (allowing tourists into a Park area) from practicing their religion. If that action is unconstitutional, subsequent government action restoring the religion to its previous position would neither coerce religious belief nor cause excessive government entanglement; rather, such action would merely insure that the Navajo are free to rely on their own beliefs. ${ }^{93}$

In correcting a free exercise violation, there is little danger that the government will corrupt individual conscience or place its imprimatur on the religion. Adherents of the religion are left free to choose whether or not to practice their rituals. There should be little concern that many Americans would adopt a particular religion merely because the government has created some exception for or extended some benefit to that religion in an effort to remove a free exercise burden..$^{94}$

Similarly, the correction of a free exercise violation will not create the danger of undue involvement of church and state. The existence of an impermissible free exercise violation implies an already existing and

91 See infra note 119.

92 638 F.2d 172 (10th Cir. 1980), cert. denied, 452 U.S. 954 (1981). Both the original government taking of the land and the secondary development of the land could arguably be viewed as free exercise violations.

9s Government action under these circumstances could be viewed as analogous to the remedy in a tort claim. Remedies are generally viewed as restoring the individual to a position equivalent to his position prior to the injury. Similarly, the "religious remedy" has both the purpose and the effect of restoring the religious group to its status quo prior to the infringement. For the Navajo, that would imply a return to the situation in which they were free to enter the land and perform solemn rituals in private.

o In the Badoni situation in particular, because the Indian religions are of a nonproselytizing nature and in fact often cannot permit outsiders to view or participate in ceremonies, there is no danger to the general public of being induced to take on the beliefs of the religion. Since, in effect, the government is acting to isolate the general public from the religion, the force of the government would not "be placed behind the tenets of one or of all orthodoxies." School Dist. of Abington v. Schempp, 374 U.S. 203, 222 (1963).

Even in situations involving groups of a more public and proselytizing bent, (i.e., Jehovah's Witnesses, Seventh Day Adventists) it is somewhat far-fetched to assume that correction of a free exercise violation would induce others to join the sect. For example, even if the government allows Sabbatarians to receive unemployment benefits although they are unable to work on Saturdays, few Americans would choose to become Sabbatarians, thus sacrificing their ability to take jobs in return for the limited benefits of unemployment. 
illegal relationship between church and state. In Badoni it could be argued that government actions in taking over and then developing a shrine area fostered an undue involvement with religion as measured by the adverse impact on freedom of religious expression, the implication of government disrespect for or even disapproval of religion, and the creation of political divisiveness along religious lines. ${ }^{95}$ In correcting those violations, government would be withdrawing itself from what was an initial entanglement with religion and increasing the separation between church and state. ${ }^{96}$

The entanglement issue requires some further analysis, however. Although Badoni presents a case in which government action to foster religious freedom-closing the park on reasonable notice for several days each year-could arguably be considered only an insignificant degree of entanglement, a more difficult situation would be presented were the Indians to request the park to be closed on a weekly basis, or perhaps more frequently, thus requiring the Park Service to police those closings and even decide when requests were valid or not. In the latter case, continual government action might be viewed as undue involvement with religion, presenting a genuine clash of free exercise and establishment. Such a clash, however, would be illusory. The original act of entanglement was the government's initial action that infringed on free exercise. It would seem specious to argue that further efforts of the government to alleviate that burden and to extricate itself from undue involvement constitute excessive entanglement in violation of the establishment clause. Under such circumstances, the real conflict, as Pfeffer argued, ${ }^{97}$ is within free exercise, not between free exercise and establishment-in this case, between the constitutionally mandated disinvolvement with religion and the legislative policy of appropriation and development of land. If the building of the Glen Canyon Dam was a violation of the Indians' constitutional rights, then perhaps the only satisfactory alternative under the hypothetical situation posited would be to close off the area to tourists altogether or to return the land to the Indians who would be allowed to regulate the privacy of their own ceremonials.

${ }^{95}$ Witness the statements of Indian leaders and their anger at what seems to be the callous indifference of the government to the needs of religious minorities. See "Message from Vine Deloria" in NIYC Journal, supra note 17, at 2.

- That view of government action to decrease or avoid entanglement was suggested in Walz v. Tax Comm'n, 397 U.S. 664 (1970), in which the Court stated that "[g]ranting tax exemptions to churches necessarily operates to afford an indirect economic benefit and also gives rise to some, but yet a lesser, involvement than taxing them." Id. at 674-75 (emphasis added).

or See supra note 75 and accompanying text. 
The non-conflict analysis applies in all situations where a free exercise claim has been raised and where government action can arguably be viewed as an attempt to remedy or avoid the free exercise violation. If the courts first evaluate the free exercise claim and determine that an impermissible burden has been placed on religion, they are in effect ascertaining a preexisting violation of the values of religious freedom. In Wisconsin $v$. Yoder, ${ }^{98}$ for example, the compulsory schooling laws forced members of the Amish faith to choose between violating their religious beliefs or disobeying government dictates. The removal of that pressure did not lend government support to the Amish faith. Individuals were free to practice the religion or not, as they chose, and the value of voluntary support of religion was fostered. Similarly, the government acted to separate itself from religion by lessening the impact of government dictates on religious belief, by refraining from implicitly expressing disapproval of those beliefs, and by lessening the threat of political strife and divisiveness along religious lines. The Court concluded as much when it stated: "The purpose and effect of such an exemption are not to support, favor, advance, or assist the Amish, but to allow their centuries-old religious society . . . to survive free from the heavy impediment compliance with the Wisconsin compulsory-education law would impose."

Alternatively, in situations where it appears that government action violates the values underlying the establishment clause by advancing (or inhibiting) religious practice, the appropriate conclusion is not that the establishment clause preempts free exercise, but rather that such government action has not been shown to be necessary to correct or ameliorate some other government infringement of religion. For example, in Committee for Public Education v. Nyquist ${ }^{\mathbf{1 0 0}}$ the court held unconstitutional a law providing tuition grants for students attending church schools and suggested (in answer to the claim that the grants were merely intended to foster free exercise) that in certain circumstances the establishment clause must dominate free exercise claims. ${ }^{101}$ A preferable analysis would have been to state that no valid free exercise claim had been advanced, and therefore that no conflict existed between the clauses. ${ }^{102}$ That is, since it was not argued that the compul-

98406 U.S. 205 (1972).

थ0 Id. at 234 n.22.

100413 U.S. 756 (1973).

101 Id. at 788-89. See supra notes $48-49$ and accompanying text.

102 See Tribe's study of cases involving release time for religious instruction in which he distinguishes McCollum v. Board of Educ. 333 U.S. 203 (1948) (invalidating the use of school facilities for religious instruction during school time) from Zorach v. Clauson, 343 U.S. 306 (1952) (upholding a program in which students were released 
sory public school education laws significantly burdened the free exercise of religion in the absence of a compelling governmental interest, the state law providing private school tuition grants was not enacted to cure a free exercise violation, and thus the case did not involve a conflict between the clauses. ${ }^{103}$

In sum, then, when a valid free exercise claim has been proven, government action to remedy or avoid the violation will operate to promote the underlying goals of the establishment clause. When viewed in the perspective of the underlying purposes of the establishment clause, the two clauses cannot conflict.

\section{The Political Process Argument}

There can be no question that when the legislature acts to aid or confer a benefit on religion, there must be some concern over whether such action violates the establishment clause. Given political reality, however, that concern should not lead to a finding of an establishment clause violation in all such cases. ${ }^{104}$ Legislatures are, for the most part, comprised of representatives of the mainstream religions. It is unlikely that they would pass laws burdening mainstream religions; it is much more likely that laws will be passed that, intentionally or not, benefit the majority and burden minority or nonmainstream religions. ${ }^{105}$ The

from public school classes to attend religious instruction off the school premises) on the basis that in Zorach the program was "arguably compelled by free exercise," whereas in McCollum it was not. L. TRIBE, supra note $66, \S 14-5$, at 823-25 (emphasis in original).

${ }^{203}$ The Court noted that the state's purpose in enacting the private school tuition grants was to maintain a healthy alternative to public education and to avoid any significant increase in the number of nonpublic school pupils transferring to the already financially troubled public schools. Nyquist, 413 U.S. at 764-65. Thus, the purpose was not to relieve any burden on free exercise caused by the compulsory education laws.

104 "The First Amendment does not prohibit practices which by any realistic measure create none of the dangers which it is designed to prevent . . . " School Dist. of Abington v. Schempp, 374 U.S. 203, 308 (1963) (Goldberg, J., concurring).

108 Representative Udall made this point cogently in his remarks to the House concerning passage of AIRFA:

Mr. Speaker, this Country is primarily a Christian country with a large Jewish population and substantial numbers of people practicing various other European and Asian religions. Were we to consider legislation which adversely impacted upon these religions and infringed upon the first amendment right to the free exercise of religion, we would, from our own knowledge and background be aware of that impact and would modify the legislation to eliminate the offensive language.

But the traditional religions of the native American people are not our religions and we are unaware of practices, rites, and ceremonials of these religions. We have, in the past, enacted legislation where we have unknowingly brought about the infringement of the religious rights of the Indians. 
religion clauses of the first amendment protect against these tendencies, the free exercise clause acting to unburden the minority religion, and the establishment clause preventing undue benefit for the majority religion. Veiwed in this light the clauses do not conflict.

Should a minority religion become burdened, the free exercise clause may mandate that the burden be alleviated. If the minority religion can persuade the legislature to act so as to relieve the burden, the affirmative governmental action should not be deemed to violate the establishment clause, as long as such corrective action does not go beyond restoring the minority religion to its position prior to the infringement. The minority is merely avoiding an infringement that probably would not be faced by the mainstream religions and the legislature is not acting to benefit the religious majority. Thus, it is improper to hold, as did the court in Badoni, ${ }^{108}$ that affirmative governmental action to remove a free exercise burden is barred by the establishment clause. ${ }^{10 z}$

Most free exercise cases have involved minority religions unable to rely on the political process for protection of their religious rights. ${ }^{108}$ Legislative or judicial action to relieve the burden would not be necessary had prior legislative action imposing the burden never taken place. Thus, the action to relieve the burden merely serves to treat all religions equally. This basic goal is not new. As discussed earlier, the Court in Sherbert $v$. Verner ${ }^{109}$ held that the extension of unemployment benefits to those who refused to work on Saturdays did not foster the establishment of the Seventh-Day Adventist religion; rather, it reflected the "governmental obligation of neutrality in the face of reli-

\footnotetext{
124 Cong. REc. 21,444 (1978).

106638 F.2d at 178-79. See supra notes $32-34$ and accompanying text.
}

107 A somewhat similar idea was expressed in a Note arguing for a dual definition of the term religion-broad for free exercise purposes, narrow for establishment purposes-as a way to avoid the conflict dilemma. Under that analysis, the existence of a religion for establishment purposes depended on "(1) the power possessed by the followers of a practice or belief and (2) the extent to which that practice or belief is generally recognized as religious." Note, supra note 89 , at 1086 . The author recognized that this definition may enable fringe religious groups to be aided without violating the establishment clause but considered this not to be a problem because (1) the underlying values of the establishment clause will not be harmed; (2) adherents of similar fringe groups can demand equal treatment; and (3) recipients of aid will be members of small and politically powerless groups which are unlikely to receive substantial benefits to begin with. "Certainly the possibility that tiny, powerless, and unpopular minorities will receive substantial benefits at the hands of the majority is far from the concern that has traditionally triggered strict judicial scrutiny." Id. at 1088 n.144.

108 See, e.g., United States v. Lee, 455 U.S. 252 (1982) (Amish claim); Thomas v. Review Bd., 450 U.S. 707 (1981) (Jehovah's Witness claim); TWA, Inc. v. Hardison, 432 U.S. 63 (1977) (Worldwide Church of God claim); Wisconsin v. Yoder, 406 U.S. 205 (1972) (Amish claim); Sherbert v. Verner, 374 U.S. 398 (1963) (Seventh-Day Adventist claim); Braunfield v. Brown, 366 U.S. 599 (1961) (Jewish claim).

109374 U.S. 398 (1963). 
gious differences."110

Cases in which the establishment clause was properly used to invalidate government actions can be divided into two groups: those in which it was not shown that prior government action unduly burdened the free exercise of religion, and those in which a free exercise violation was present, but government action went beyond simply remedying the violation. Committee for Public Education v. Nyquist ${ }^{111}$ is an example of those in the first group. In Nyquist, because it was not shown that state education laws burdened the free exercise of religion, the action of the legislature granting tuition reimbursements to parents who enrolled their children in parochial schools was not taken to remedy a free exercise violation. Since the government is not obligated to pay for religious education, but only to provide public education, the action of the legislature could either be viewed as inuring to its own perceived benefit in promoting religion over nonreligion, or may have been the result of a political coalition with the minority religion. Similarly, in School District of Abington $v$. Schempp, ${ }^{112}$ since there was no underlying free exercise violation; the mandated school prayer in effect advanced religion over nonreligion and benefitted the majority.

A comparison of Zorach v. Clauson ${ }^{113}$ and McCollum v. Board of Education ${ }^{114}$ nicely illustrates those cases that fall in the second group. Both cases may have involved an underlying free exercise claim that compulsory education interfered with the weekly religious instruction of minority group children. (Had the group been a "majority" religion, the political process would have protected religious exercise, perhaps by originally insuring that compulsory education laws did not interfere with religious instruction. Such protection already exists, in fact, since no school systems hold classes on Sunday, a practice which would violate the religious freedom of the majority.) In Zorach, the release time program restored the position of the religious group to the status quo prior to interference by the compulsory education laws. ${ }^{115}$ In contrast, in $M c$ Collum, under the same implied free exercise claim, the state action went beyond restoring the status quo and placed religion in a better position than it would have been absent the compulsory education laws (i.e. by providing public facilities and placing the power and prestige of the school behind religious instruction). ${ }^{118}$ This analysis then

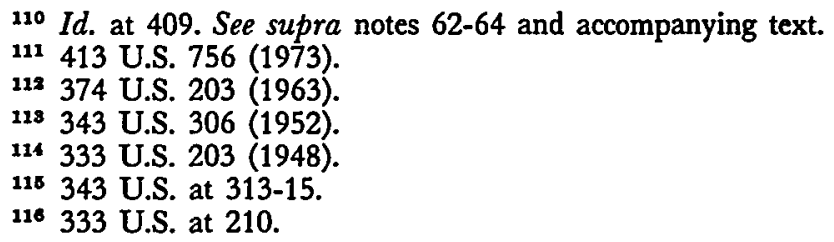


can reconcile the Zorach and McCollum decisions by positing an underlying free exercise violation in each that was appropriately remedied in Zorach, but inappropriately remedied in McCollum.

In summary, the non-conflict approach assumes that appropriate government action to remedy or avoid a free exercise violation is a mandated concession that goes against the immediate interest of the majority and is necessary to restore the minority to some status quo existing prior to the free exercise violation. In neither situation (acting to restore a burdened minority to its unburdened position or acting against the self-interest of the majority) is there any serious danger of violating the underlying values of the establishment clause. ${ }^{117}$

\section{Logical Priority}

In recent cases involving establishment claims, the Court has consistently invoked a three-part test that evaluates a government action by determining whether it reflects a secular purpose, whether it has a primary secular effect that neither advances nor inhibits religion, and whether there is excessive entanglement of government with religion. ${ }^{118}$ Because this test involves an assessment of both purpose and effect, it can only be answered after any free exercise claims have been evaluated. ${ }^{119}$ The free exercise assessment provides data concerning the gov-

112 The most difficult and most crucial aspect of the analysis will be to determine if government action is genuinely directed in response to a valid free exercise claim. When government acts in a fashion that appears to be favoring minority religions, there are three possible interpretations: (1) the action is in response to a shift in political power, perhaps because a coalition of minority groups have gained control of the political process; (2) the action reflects the favored position of one minority group, thus creating an equal protection problem (for example, if the government allowed the Amish to be exempted from compulsory education laws but denied the privilege to other groups); and (3) the action is in response to a valid free exercise claim. The nonconflict analysis, therefore, does not suggest that all government actions on behalf of minority groups will not violate the establishment clause, but only those actions in response to a valid free exercise claim.

118 See, e.g., Larkin v. Grendel's Den, Inc., 103 S. Ct. 505, 510 (1982); Widmar v. Vincent, 454 U.S. 263, 271 (1981); Wolman v. Walter, 433 U.S. 229, 236 (1977); Roemer v. Board of Public Works, 426 U.S. 736, 748 (1976); Meek v. Pittenger, 421 U.S. 349, 358 (1975); Hunt v. McNair, 413 U.S. 734, 741 (1973); Tilton v. Richardson, 403 U.S. 672,678 (1971).

The Supreme Court has found an impermissible purpose very infrequently. See Stone v. Graham, 449 U.S. 39 (1980) (per curiam) (state law requiring posting Ten Commandments on the wall of public school classrooms found to have religious purpose); Epperson v. Arkansas, 393 U.S. 97, 107-09 (1968) (prohibition on teaching of evolution in schools found to have a religious purpose).

${ }_{119}$ A government action can be upheld (1) if there is found to be no infringement on the free exercise of religion; or (2) if there is a state interest of sufficient magnitude to override any free exercise infringement. For a statement of this standard see United States v. Lee, 455 U.S. 252, 257 (1982); Wisconsin v. Yoder, 406 U.S. 205, 214 (1972); 
ernment purpose-to correct an illegal burden on religion, to protect constitutional values, to foster voluntary religious practices-all permissible "secular" purposes; and the effect of the government action-to restore the burdened group to a preexisting status quo. Thus, in any situation in which an establishment clause violation is raised, the courts must first determine whether a free exercise violation is involved: (a) if the government action can be viewed as an action to remedy or avoid a free exercise violation by the government; (b) if such government action restores the status quo that existed before the infringement; and (c) if the action goes no further than necessary to restore this status quo, that is, to remedy the violation, then the action can be said to have both a proper purpose and a proper effect and will not be a violation of the establishment clause. Furthermore, if the correction of the free exercise violation results in any perceived undue entanglement of government with religion, the burden will be on the government to devise a different method for correcting the free exercise violation.

Given this application of the establishment clause test, no conflict is possible when government action is taken to correct an infringement on free exercise. Instead, the clauses are in a relationship of logical priority. Two procedural conclusions result. First, the only analysis pertinent under a free exercise claim is the applicable free exercise test to determine whether there is an infringement of religious exercise and if so, whether compelling governmental interests mandate such infringement; ${ }^{120}$ and second, when an establishment clause claim is invoked, the court must first decide whether there is an underlying free exercise claim and whether the contested activity can be seen as a remedy of the infringement or an attempt to avoid the initial violation. This latter approach is logically required because the free exercise test provides necessary data for the establishment test.

\section{B. Application of the Non-Conflict Approach}

The non-conflict approach can be used to reach the same results mandated by the Supreme Court cases, but can do so in a manner much more explicitly revealing of underlying assumptions and without positing a conflict in the constitutional text. When the Court's free exercise analysis indicates impermissible infringements on religion, these can be corrected without any danger of a conflict with the establish-

Sherbert v. Verner, 374 U.S. 398, 407 (1963). See also Pfeffer's discussion of this test as akin to the "clear and present danger" test used in free speech cases. L. PFEFFER, supra note 74 , at $500-03$.

${ }^{120}$ See supra note 119 and accompanying text. 
ment clause as long as the corrective action does no more than restore the religion to its unburdened position. For example, in Yoder, ${ }^{121}$ the Court could not have ruled that public schools were required to provide training in the Amish faith to Amish students, since this would have advanced the religion beyond its original unburdened status.

In the establishment cases, the court must first decide whether there is an underlying free exercise claim or the possibility of a free exercise violation that government action sought to avoid. There may have been such free exercise violations in those cases in which the Supreme Court found no establishment clause violations: Everson $v$. Board of Education ${ }^{122}$ (a claim that for the state to provide bus transportation for public school students but not parochial school students would be a free exercise violation); Zorach ${ }^{123}$ (a free exercise claim for a faith to be allowed to provide weekly religious instruction to its members' children); and Walz $v$. Tax Commission ${ }^{124}$ (a free exercise claim not to be burdened with a duty to pay taxes that might harm the religion).

Because the Court was not explicit in its analysis, it is also possible that the free exercise claim in these cases was rejected. Under these circumstances, the standard three-part establishment clause test would be applied to determine whether the government action, although not required to remedy a free exercise violation, would be permitted.

Cases in which the Court upheld the establishment challenge indicate (under the non-conflict approach) that any underlying free exercise claim was found to be invalid (or, at least, the infringement was permissible). ${ }^{125}$ In those cases, free exercise did not require, nor did establishment permit, the government action.

For sake of illustration, the theory will be applied to the Badoni case and to two recent Supreme Court decisions, Widmar $v$. Vincent ${ }^{128}$ and Larkin v. Grendel's Den, Inc. ${ }^{127}$

In Badoni, plaintiffs alleged that government actions infringed on their free exercise of the Indian religion. It was then the role of the court to evaluate those claims in light of the mandated free exercise

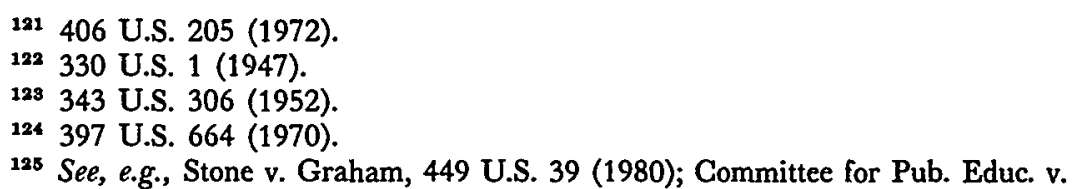
Nyquist, 413 U.S. 756 (1973); Lemon v. Kurtzman, 403 U.S. 602 (1971); School Dist. of Abington v. Schempp, 374 U.S. 203 (1963); Engel v. Vitale, 370 U.S. 421 (1962); McCollum v. Board of Educ., 333 U.S. 203 (1948).

126454 U.S, 263 (1981).

127103 S. Ct. 505 (1982). 
analysis and to decide whether there was in fact such infringement, and whether compelling state interests justified the infringement. ${ }^{128}$

For the sake of argument, had a valid free exercise claim been found, and had the government action restored the religion to its unburdened situation, the first two prongs of the establishment clause test ${ }^{129}$ would be satisfied. The purpose of the government in protecting the shrine areas would not be to foster Indian religion, but only to remove an illegal impediment to religious practices. ${ }^{130}$ The effect would similarly not be to advance or inhibit the religion. The religion would be returned to its status before the government encroachment. Practitioners would be free to worship as they chose, and the religion would flourish or die solely through the faith of its adherents. Certainly no members of the public would be coerced into joining the religion, especially since the effect of government action would be to deny access to the public to view the private ceremonies.

Finally, there could be no excessive entanglement. If the courts found government action (for example, keeping tourists out at certain times) to be an excessive involvement with religion, one available alternative would be to require total removal of the government from the land, i.e. returning the land to the tribes who could then police it themselves. In other words, once the government has unconstitutionally entangled itself with religion, it cannot be argued that government efforts to extricate itself or to alleviate the injustice would be forbidden because of excessive entanglement.

Larkin v. Grendel's Den, Inc. ${ }^{\mathbf{1 3 1}}$ presents an interesting contrast to Badoni. Plaintiffs in that case contested the validity of a Massachusetts statute which delegated to churches and schools veto power over the issuance of a liquor license to an establishment within 500 feet of the church or school. The Court ruled that the law failed the establish-

${ }^{128}$ See supra note 119. A sensitive evaluation of the nature and needs of Indian religions certainly might have revealed that the burden on free exercise was quite significant. Further, since the "compelling" government interest involved recreational and tourist facilities, the significant infringement might not have been justified.

129 See supra text accompanying note 118 .

130 Compare that to the purpose of AIRFA as expressed in a letter written by Assistant Attorney General Patricia M. Wald. Wald stated that Senate Report No. 95709 made clear

that the resolution's purpose is 'to insure for traditional native religions the same right of free exercise enjoyed by more powerful religions. However, it is in no way intended to provide Indian religions with a more favorable status than other religions, only to insure that the U.S. Government treats them equally.'

124 Cong. Rec. 21,444 (1978).

131 103 S. Ct. 505 (1982). 
ment clause test because it delegated a governmental power (liquor store licensing) to religious institutions, thus entangling government with religion and creating the danger of divisiveness along religious lines. ${ }^{132}$ The Court stated that a more valid approach to achieving the same governmental purposes would have been an absolute ban on liquor outlets within reasonable distances from "churches, schools, hospitals and like institutions."13s

In Grendel's Den there was no underlying free exercise violation since government action had not burdened religion in any fashion. No corrective action was therefore required and the purpose and effect of the Massachusetts law must be examined independent of any free exercise claims. Even assuming there had been a valid free exercise claim requiring correction, the Massachusetts law went beyond restoring the status quo and instead gave religious institutions broad discretionary powers unnecessary to the correction of the violation.

The non-conflict approach reaches the same result as the Court, but would do so by explicitly applying the free exercise analysis before examining the establishment claims. Such an approach makes clear the assumptions of the Court and prevents a reading of the two clauses as conflicting.

Widmar $v$. Vincent ${ }^{\mathbf{1 3 4}}$ involved the decision by a state university to exclude student religious groups from university meeting facilities available to other student groups. The university argued that to allow religious use of the state supported facilities would be a violation of the establishment clause. The Court held that the university policy was an impermissible content-based regulation of speech, and further stated that an open forum policy would not be a violation of the establishment clause since there would be merely an incidental benefit to religion and no imprimatur of state approval on religious sects or practices. ${ }^{135}$

In his dissent, Justice White, who most directly addressed the underlying free exercise claim of the excluded religious group, relied in part on conflict analysis. He found there to be only a minimal burden on religion, offset by the state's legitimate interest in avoiding establishment problems and maintaining the separation between church and state. ${ }^{136}$ Justice White's analysis suggests that a free exercise claim can be struck down by an establishment claim.

In contrast, the non-conflict approach would first address the issue 
of an underlying free exercise claim and ask whether the denial of meeting privileges was an infringement of the free exercise rights of the group. Such an infringement might be justified by a compelling state interest-perhaps the need to limit use of the facilities to groups of a certain size or the need to reserve the facilities for purely universitywide functions-but would not be justified solely by a perceived need to uphold the establishment clause. If an infringement existed and if there were no compelling state interest to justify the burden, free exercise requires that religious groups be permitted access to the facilities, and establishment would permit such access. If no free exercise violation existed, then the Court would apply its establishment analysis, looking to other factors to determine purpose and effect. The majority opinion in Widmar does not reach the issue of whether an underlying free exercise violation existed but does state that the provision of benefits to a broad spectrum of groups indicates primarily a secular effect. ${ }^{\mathbf{1 3 7}}$ Under the non-conflict approach this could be interpreted to mean that if the university's grant of privileges to religious groups (along with secular groups) was an effort to avoid a free exercise burden, then the effect (and purpose) of such policy would be simply to retain the status quo in which religious groups are neither advanced nor inhibited and would not be a violation of the establishment clause. The Court comes tantalizingly close to examining the underlying free exercise claim as one way to determine an establishment violation, but never does so explicitly.

\section{SUMmary AND CONCLUSIONS}

There are four possible relationships between the two religion clauses of the first amendment: (1) free exercise requires a government action that establishment forbids; (2) free exercise requires action that establishment permits; (3) free exercise does not require but establishment permits such action; and (4) free exercise does not require and establishment does not permit the action. Two and four are nonproblematic. It is one and three that create difficulties. ${ }^{138}$ The Court

137 Id. at 274. In Widmar, the Court found that to not allow religious groups to use the facilities infringed free speech. $I d$. It is possible to argue that government action designed to remedy the infringement of any constitutional right, not just free exercise, can never violate the establishment clause.

188 The comment has not dealt at all with situation (3). It could be argued that (3) like (1) is an empty category, and if free exercise does not require, establishment will not permit. The Court and commentators, however, have sometimes espoused an opposite approach.

The general principle deducible from the First Amendment and all that has been said by the Court is this: that we will not tolerate either govern- 
has suggested that situation one (free exercise requires but establishment does not permit) is possible and that in those circumstances, either one or the other of the clauses will be dominant. It is the thesis of this Comment that situation one does not exist since the two clauses can and should be viewed as complementary, operating in a relationship of logical priority.

The difference in result between the non-conflict approach and an approach that says the two clauses conflict but that the free exercise clause is dominant ${ }^{139}$ is probably small. The non-conflict approach, however, is more natural and less strained. It is not necessary to weigh the two clauses to determine which one should "win out," nor is it necessary to restrict the freedoms secured by either. Finally, it is always desirable to interpret the Constitution as being internally consistent.

The approach developed in this Comment differs from Kurland's strict neutrality approach ${ }^{140}$ in that the former allows the government to take action based on religious classifications (if, of course, it does so to rectify a free exercise infringement). It differs from Pfeffer's ${ }^{141}$ in that it more clearly sets forth the logical priority of the clauses, rather than simply relying on their common evolutionary development.

Three arguments were advanced for the non-conflict approach. First, the underlying purposes of the establishment clause would be served, and the dangers intended to be protected against would be avoided by permitting free exercise violations to be rectified without

mentally established religion or governmental interference with religion. Short of those expressly proscribed governmental acts there is room for play in the joints productive of a benevolent neutrality which will permit religious exercise is exist without sponsorship and without interference.

Walz, 397 U.S. at 669 . The Court further stated, "[t]he limits of permissible state accommodation to religion are by no means co-extensive with the noninterference mandated by the Free Exercise Clause." Id. at 673.

This "benevolent neutrality" expressed in Walz has been interpreted as permitting religious accommodation regardless of whether or not the free exercise clause would be violated. Wheeler, Establishment Clause Neutrality and the Reasonable Accommodation Requirement, 4 Hastings Const. L. Q. 901, 932 (1977). It is sometimes referred to as a "zone of legislative discretion," the area between the establishment and free exercise clauses in which accommodation to religion is neither forbidden nor required.

Not only must the no-aid or neutrality concept be subordinated to the necessities of free exercise, but an area of legislative discretion must be allowed where a state may choose to advance the cause of religious freedom even at the expense of not being completely neutral. Indeed this may be described as the larger or benevolent neutrality.

Kauper, supra note 59, at 75. See also, Note, Anderson v. General Dynamics Convair Aerospace Division: First Amendment Establishment Clause Challenge to Title VII's Mandated Accommodation of Religion, 76 Nw. U.L. REv. 487 (1981).

${ }_{130}$ See supra notes 54-64 and accompanying text.

140 See supra notes $72-73$ and accompanying text.

141 See supra notes 74-75 and accompanying text. 
fear of violating the establishment clause.

Second, the importance of the free exercise clause lies in the protection it affords to minority religions-protection from both deliberate government attempts to eradicate religion and general policies that encroach in an insensitive manner on the free exercise of religious groups. ${ }^{142}$ The dangers averted by the establishment clause are most likely to arise when the majority religion attempts to benefit itself, since government efforts are highly unlikely to attempt to advance (as opposed to unburden) the religions of minority groups. The dangers underscored by the establishment clause are thus not present when the government steps in to alleviate a burden on the free exercise of religion. The court implicitly has taken just such an approach in various cases in which it permitted exemptions from laws of general applicability on the basis of religion. ${ }^{143}$

Finally, the non-conflict approach is mandated by the logical relationship of the two clauses. The free exercise determination reveals the purpose and effect of a government law, information necessary for performing the mandated establishment clause test. In all circumstances in which an establishment clause claim has been raised, the court must therefore determine first, whether the government action was intended to rectify a valid free exercise claim, and second, whether the action did no more than restore the status quo and return the religion to its unburdened position.

Unfortunately the Court has never explicitly articulated this nonconflict approach, and lower courts have been left with a test so flexible in nature that it can be used to strike down valid free exercise claims. Such a use of the establishment clause in effect allows the courts to avoid a careful analysis of the free exercise claim and the difficult process of determining whether an infringement is allowable by virtue of a compelling state interest. In a sense that is an abrogation of the responsibility of the courts. Rather than stating the priorities outright-e.g., the needs of tourists and recreation facilities outweigh the burden imposed on minority religions-the courts have been able to avoid making that statement by claiming that any corrective action would violate the establishment clause. That use of the establishment clause not only violates the underlying purposes of the two religion clauses but allows the

162 Indians are an example of such a religious minority, burdened with a long history of government efforts that have all too often been successful in eradicating the Indian way of life. Thus, Native Americans are precisely that category of people who come under the special protection of the free exercise clause, those minorities whose religious interests will not entirely be protected by the political process.

14 See, e.g., Thomas v. Review Bd., 450 U.S. 707 (1981); Wisconsin v. Yoder, 406 U.S. 205 (1972); Sherbert v. Verner, 374 U.S. 398 (1963). 
majority to infringe upon the religious needs of the minority group without admitting the value judgments involved. ${ }^{144}$

A non-conflict approach would not permit such use of the establishment clause when a legitimate free exercise claim is involved, but instead would require the courts to apply a full and stringent free exercise analysis and to state openly their conclusions so that they could be assessed through the judicial and political processes. Such an approach prevents the courts from justifying a burden on minority rights under the guise of constitutionalism.

144 Compare the remarks of Rep. Udall on the purpose of AIRFA: "It is the intent of this bill to insure that the basic right of the Indian people to exercise their traditional religious practices is not infringed without a clear decision on the part of the Congress or the administrators that such religious practices must yield to some higher consideration." 124 CONG. REC. 21,444 (1978). 